\title{
$131^{\text {ste }}$ BESTUURSVERGADERING,
}

van 24 SeptemRer 1870.

Tegenwoordig de heeren Sloet van de Beele (OnderVoorzitter), Bachiene (Penningmeester), Banck, Blommendal, van Limburg Brouwer, Kern, Niemann en Robidé van der Aa (Secretaris): Afwezig de heer Gevers Deynoot wegens bezigheden elders, de heer Hoffiman wegens ongesteldheid, de heer Dumontier wegens verblijf in het buitenland.

De heer Sloet van de Beele is belast met het voorzitterschap.

De notulen van het verhandelde in de vorige vergadering worden gelezen en goedgekeurd.

I. Voor de bibliotheek zijn ingekomen de volgende boekwerken :

Van de Kon. Academie van Wetenschappen te Amsterdam:

Verslagen en mededeelingen. Afd. Natuurkunde 2e reeks, 4e dl. 3 e st.

Van het Kon. Instituut van Ingenieurs:

Tijdschrift 1869-1870 5e afl.

Van het Historisch Genootschap:

Kroniek 25e jaarg.

C. M. Davies. Memorials and times of P. P. J. Q. Ondaatje.

Van de Ned. Maatschappij ter bevordering van Nijverheid:

Tijjschrift 3e reeks deel XI, 7e en $8 \mathrm{e}$ stuk.

Van het Ned. Zendelinggenootschap :

Verslag van den staat en de werkzaamheden in 1870 .

Van de Keizerl. Academie van Wetenschappen te Weenen:

Sitzungsberichte der phil. hist. classe. Band LXIII, LXIV heft I.

Sitzungsberichte der mathem. naturw. classe. Jahrg. $1970 \mathrm{n}^{0}$. $X$ VIII-XX.

Van de Société de Géographie te Parịjs:

Bulletin Juni 1870.

Vau de Royal Geographical Society te Londen: 
Journal vol. 39.

Van de Asiatic Society of Bengal:

Journal 1870 Part. II no. II.

Proceedings 1870 n 0.5 en 6.

Bibliotheca Indica. New Series no. 182-186, 188-189.

Van de Ceylon Branch of the Asiatic society:

Jourual $1867-1870$ part. II.

Van het Smithsonian Institution:

Contributions to kwowledge vol XVI.

Miscellaneous collections vol VIII-IX.

B. Anderson. Journey to Musardu.

Van de Académie impériale des sciences de St. Petersbourg:

Mémoires VIJe Serie tome XV no. 5-8.

Bulletin Tome XV feuilles $1-16$.

Van de Société impériale Géographique de Russie.

Extraits des publications de la société en 1856 et 1857 .

Otcet Imperatorskago Russkago Geographiceskago Obcestwa. 1869.

Izwjastija Imperatorskago Russkago Geographiceskago Obcestwa. Deel VI no 1-4.

Van de Deutsche morgenländische Gesellschaft:

Abhandlungen für die Kunde des Morgenlandes. Band V no 3

Van den Schrịjver:

E. Behm. Die geographischen Gesellschaften und Publikationen.

II. De Voorzitter deelt mede, dat zijn ingekomen de volgende brieven :

a. Van de heeren C. A. Jeekel en A. W. T. Juyuboll, houdende kennisgeving, dat zij het hun aangeboden lidmaatschap aannemen.

b. Van het Bataviaasch Genootschap van kunsten en wetenschappen, daarbij toezendende afdrukken van Kawi-opschriften.

De Voorzitter herinnert, dat een exemplaar van deze afdrukken o. a. ook is toegezonden aan de Koninklijke Academie van Wetenschappen te Amsterdam en dat de letterkundige afdeeling van dit lichaam deze stukken gesteld heeft in handen van eene commissie, met verzoek daaromtrent rapport uit te brengen. Daar ons medelid Prof. Kern reeds deel dier commissie uitmaakt, acht de Voorzitter het weuschelijk, dit rapport af te wachten, met welk gevoelen de vergadering zich vereenigt. 
c. Van den Minister van Koloniën dd. 16 Juli 1870, waarin te kennen wordt gegeven, dat geen bezwaar bestaat tegen het overdrukken in de Bijdragen van de nota's der heeren Roorda en Pijnappel en Cohen Stuart omtrent de spelling der Indische plaatsnamen.

Deze rapporten worden alsnu tot opneming in de Bijdragen bestemd.

d. Van den Minister van Koloniën dd. 5 Sept. 1870, waarbij, in antwoord op des Instituuts schrijven, wordt medegedeeld, dat hij bezwaarlijk reeds nu eene toezegging kan doen aangaande de bestelling van een zeker aautal exemplaren van Niemann's Bloemlezing voor rekening van het Departement van Kolonien. "Eerst moet - aldus wordt in die missive gezegd het Indisch bestuur in de gelegenheid zijn gesteld, zijn oordeel uit te spreken over de geschiktheid van het werk voor het inlandsch onderwijs. Daarover is de Gouverneur-Generaal gehoord, met uitnoodiging het antwoord te bespoedigen en zich, zoo daartegen geene bedenking gevonden wordt, te verklaren omtrent de wenschelijkheid der bestelling, zonder van het 2e deel der Bloemlezing kennis te hebben genomen."

De. vergadering besluit deze missive voor kennisgeving aan te nemen en een nader schrijven af te wachten.

e. Van Commissarissen des Instituuts te Batavia, waarbij:

$1^{0}$. wordt toegezonden de rekening-courant, loopende van 1 Januari 1869 tot 31 Mei 1870 en sluitende met een saldo ten behoeve van het Instituut ten bedrage van $f 606.50$, ter voldoening waarvan wordt overgemaakt een wissel tot dit bedrag.

20. wordt medegedeeld, dat het voor het Instituut gemaakte afschrift van het Alfabetisch register op de plakkaten der Indische regeering van 1602-1762 (zie Notulen van 23 Mei 1868) aan de welwillende bezorging van den heer van den Muysenbergh is toevertrouwd.

3 . wordt bericht, dat de heer H. J. Bool door zijne drukke ambtsbezigheden, nog vermeerderd door eene bijzondere opdracht, zich genoodzaakt acht, zich aan alle andere werkzaamheden te onttrekken en uit dien hoofde als Commissaris van het Instituut af te treden, terwijl verder nieuwe leden en een nieuwen kommissaris worden voorgesteld.

De Penningmeester bericht, dat de wissel naar behooren is geincasseerd en de Secretaris, dat het bedoelde Alfabetisch Register is ontvangen en ter tafel ligt. 
$f$. Van de heeren Winsser, de Lange en Co. te Batavia, houdende mededeeling, dat zij op verzoek van het lnstituut zich met de ontvangst der contributies in Indië hebben belast en dat zij bereids een bedrag in kas hebben genomen.

Onder daukbetuiging voor de welwillendheid der genoemde firma wordt deze missive voor kennisgeving aangenoinen.

\section{De Secretaris deelt mede :}

a. dat de drukker des lnstituuts, de heer H. L. Sinits, een nota heeft ingezonden wegens verkochte Bijdragen en werken in 1869, waaruit blijkt, dat in dat jaar verkocht is voor een bedrag van $f$ 359.75, waarvan het Instituut bekomt 50 pCt. of $f 179.87 \frac{1}{2}$;

b. dat aan den heer H. C. Klinkert, op zijn verzoek, is teruggezonden zijne vertaling van een Maleisch gedicht op den heldendood van den generaal Michiels, daar ZEd. bezwaar makte, den maleischen tekst van dit gedicht over te zenden.

IV. De Voorzitter stelt thans an de orde het nemen eener beslissing omtrent het door wijlen den heer Hooykaas bewerkte Repertorium op de koloniale litteratuur en herinnert daarbij aan het advies door den heer Robidé van der Aa in de vorige vergadering uitgebracht. Overwegende, hoeveel arbeid er nog vereischt wordt, alvorens het handschrift ter perse kan gaan, en vooral dat het twijfelachtig genoemd kan worden, of door de gevolgde wijze van bewerking, wier groote uitvoerigheid de voornaamste hinderpaal voor de voltooiing en uitgave is, het Repertorium wel geschikt is voor hen, die het zouden moeten gebruiken, besluit de vergadering eenparig, hoeveel leed het haar ook doe, tot dit resultaat te geraken, van de uitgave af te zien. Het Bestuur spreekt echter gaarne den wensch uit, dat het handschrift van wijlen den heer Hooykaas in een onzer openbare boekerijen bewaard blịjve ten dienste van de beoefenaars der koloniale wetenschap, die uit dit handschrift, zelfs in zij̣n tegenwoordigen onvoltooiden toestand, veel nut zullen kunnen trekken.

Van dit besluit der vergadering zal, behalve aan dr. J. Hooykaas te Schiedam, broeder vau wịlen den vervaardiger, door wieus tusschenkomst de toezending aan het Institunt heeft plaats gehad, ook aan het Departement van Koloniën worden kennis 
gegeveu, daar de Minister bereids een subsidie voor de uitgave had toegezegd.

V. Benoeming van ledlen. Tot gewoon lid wordt benoeind, op voorstel van den Secretaris, de heer D. W. Rost van Touningen, administrateur der tinmịnen te Billiton, die in de volgende maand weder naar Indië vertrekt, en op voorstel van Commissarissen in Oost-Indië, de heeren: mr. J. J. de Graaff, mr. A. Th. Heyligers en K. L. van Schouwenburg, leeraren aan het gymnasium Willem III te Batavia en G. C. Klerk de Reus, predikant te Padang.

Tot buitenlandsche leden worden benoemd de heeren Martin Haug, professor te Munchen, voorgesteld door den heer Kern en Angelo de Gubernatis, professor te Florence, voorgesteld door den heer van Limburg Brouwer.

\section{Benoeming van een kommissaris in Oost-Intiè. Daar} de heer Bool volgeus het boven medegedeeld schrijven zijn ontslag als kommissaris heeft verzocht, wordt hem dit, hoezeer met leedwezen, verleend onder dankbetuiging voor de door hem aan het Instituut bewezen diensteu en op voordracht van hem en zi.jn. mede-kommissaris in zijue plaats benoemd Mr. J. J. de Graaff.

\section{Benoeming eener kommissie voor de transcriptie van} vreemde karaklers in het Latijnsch alphabet. De Secretaris, als zoodanig belast met de uitgave der geschriften van het Instituut, wijst op de her haaldelijk ondervonden moeilijkheden, wanneer Oostersche karakters in een Hollandsch opstel voorkomen, ò omdat die vreemde typeu met hunne onder en boven de letters geplaatste teekens licht tuss hen de gewone Hollandsche letters misstand veroorzaken of ook omdat de drukker van het Instituut niet de typen van al die verschillende Oostersche alfabetten bezit. Dit laatste heeft onder anderen veroorzaakt, dat het drukken van het werk van Prof. Millies zoo langzaam ging, omdat de drukker telkens de daarin voorkomende Sankritsche en Bataksche typen van andere drukkerijen moest leenen. $\mathrm{Nu}$ kan men bij het uitgeven van Oostersche teksten, waarbij men de aan iedere taal eigene letters zal moeten blịjven gebruiken, den druk aan een andere drukkerịj toevertrouwen; dit gaat echter niet voor talkundige opstellen in de Bïdragen, waariu die vreemde typen tusschen den Hollandschen tekst voorkomen, omdat het dan weder misstaan zou, 
indien de verschillende stukken niet met dezelfde Hollandsche letter gedrukt waren. Ter voorkoming dezer bezwaren ware het te wenschen, dat de taalgeleerden, die het Instituut met de vruchten van hnn onderzoek vereeren, zooveel mogelijk die vreemde karakters in het Latijnsch alfabet uitdrukten. Prof. Kern deed dit reeds in zijn opstel ter verklaring van enkele uitdrukkingen in de Javaansche Wajang-verhalen (B̈̈dragen Reeks III D. III), evenals Prof. Roorda in een opstel over hetzelfde onderwerp, dat in de onlangs verschenen, aflevering is afgedrukt. In taalkundige opstellen over het Maleisch wordt sedert lang veelal het Latijnsche alfabet in plaats van of naast het Maleische gebezigd, oundat dit laatste geen teekens voor de klinkers bezit en dus slechts zeer onvolledig de uitspraak der woorden angeeft.

Mocht dit transcribeeren der vreemde karakters in gewoon letterschrift meer in zwang komen, dan is het tevens wenschelijk, dat dit in de werken van het Instituut zooveel mogelijk op dezelfde wijze geschiede, en dat het Instituut voor zijne uitgaven een bepaald systeem van transcriptie voor de verschillende Oostersche talen aanneme. Dit is natuurlijk iets anders dan de hier vroeger meermalen behandelde kwestie der spelling van Indische namen in het Hollandsch, waarbij men zooveel mogelijk aan die taal vreemde accenten, punten of streepjes onder of boven de letters moet vermijden en waarbij men ook veilig het voor Europesche ooren niet hoorbare onderscheid tusschen sommige eigenaardige Oostersche letters kan verwaarloozen. Daarentegen zal men in een systeem van transcriptie voor wetenschappelijke opstellen van taalkundigen aard ieder vreemd karakter op een of andere wijjze moeten uitdrukken, zoodat men uit het getranscribeerde woord terstoud kan zien, hoe het in Oostersche letters moet worden geschreven. Wanneer de linguisten in den boezem van het Bestuur deze beschouwingen mochten beamen, zou de Secretaris wenschen. dat aan eene kommissie het ontwerpen van zulk een systeem van transcriptie der Oostersche talen voor de werken van het Instituut werd opgedragen,

De heer Niemann vereenigt zich gaarne met dit denkbeeld. Ter voorkoming der beschreven moeilijkheden heeft hij dan ook in de latere vellen van het werk van Prof. Millies bij verschillende woorden de Oostersche karakters getranscribeerd en in het opstel van zijue hand, dat nu voor de Bijdragen gedrukt wordt, al de Maleische, Javaansche, Bataksche en Makassaarsche woorden in ons letterschrift weergegeven. 
Na eenige woordenwisseling besluit de vergadering tot het benoemen der bedoelde kommissie en draagt de taak tut het ontwerpen van eeu systeem van transcriptie op aan de heeren van Limburg Brouwer, Kern en Niemann met verlof, om zich andere bevoegde deskundigen te adjungeeren.

Hierna sluit de Voorzitter de vergadering. 